\title{
Desiccation tolerance and cryopreservation of seeds of black poplar (Populus nigra L.), a disappearing tree species in Europe
}

\author{
Marcin Michalak $\cdot$ Beata P. Plitta • \\ Tadeusz Tylkowski $\cdot$ Pawel Chmielarz $\cdot$ \\ Jan Suszka
}

Received: 29 January 2014/Revised: 14 July 2014 / Accepted: 26 July 2014/Published online: 12 August 2014

(C) The Author(s) 2014. This article is published with open access at Springerlink.com

\begin{abstract}
Black poplar (Populus nigra L.) is a widely distributed species that plays a crucial role in riparian forest ecosystems. Due to a reduction in its natural habitats and hybridization with introduced poplar species clones, its genetic pool is decreasing and efforts are required to preserve this species. Seeds of black poplar are short-lived and quickly lose viability during conventional storage in gene banks. Therefore, in order to preserve ex situ the genetic diversity of this species, the feasibility of seed cryopreservation in liquid nitrogen (at $\left.-196{ }^{\circ} \mathrm{C}, \mathrm{LN}\right)$ for periods of $24 \mathrm{~h}$ and 2 years was investigated. Seeds were harvested from three individual trees (two provenances) and desiccated to different levels of water content (WC) in the range of $0.02-0.35 \mathrm{~g} \mathrm{~g}^{-1}\left(\mathrm{~g} \mathrm{H}_{2} \mathrm{O} / \mathrm{g}\right.$ dry mass, $\left.\mathrm{g} \mathrm{g}^{-1}\right)$ prior to immersion in LN. Seed germination was assessed after each treatment. $P$. nigra seeds tolerated desiccation to WC $0.07 \mathrm{~g} \mathrm{~g}^{-1}$ but after severe desiccation to WC $<0.05 \mathrm{~g} \mathrm{~g}^{-1}$ exhibited a significant reduction in germination. Results indicated that all black poplar seeds, regardless of origin, year of harvesting and seed quality, could be cryopreserved for $24 \mathrm{~h}$ when their WC was in the range of $0.11-0.17 \mathrm{~g} \mathrm{~g}^{-1}$. Physiology of $P$. nigra seeds showed in this paper is consistent with attributes of intermediate seed storage behavior. This study provides a foundation for
\end{abstract}

Communicated by J. Holopainen.

Electronic supplementary material The online version of this article (doi:10.1007/s10342-014-0832-4) contains supplementary material, which is available to authorized users.

M. Michalak ( ( ) B. P. Plitta · T. Tylkowski · P. Chmielarz · J. Suszka

Institute of Dendrology, Polish Academy of Sciences,

Parkowa 5, 62-035 Kórnik, Poland

e-mail: michalak_marcin81@wp.pl using cryopreservation for the ex situ conservation of P. nigra seeds.

Keywords Black poplar - Cryopreservation - Rare species $\cdot$ Seed desiccation $\cdot$ Seed water content $\cdot$ Seed storage

\section{Introduction}

Black poplar (Populus nigra L.) has a wide geographic distribution, ranging from West Europe to Central Asia and North Africa (Vanden Broeck 2003). Populus nigra, similar to the majority of Populus species, is a deciduous tree whose seeds are disseminated by both wind and water. It can also propagate vegetatively from broken branches, cuttings, and root suckers. This species is economically important and is used for soil protection and reforestation of polluted industrial zones (Popivshchy et al. 1997). It is also sometimes planted for domestic use (Tunçtaner 1995). $P$. nigra plays also a central role as a parent pool in poplar breeding programs and has contributed to the breeding of many successful interspecific hybrids (Frison et al. 1995).

Populus nigra is a major species component of softwood floodplain forest ecosystems and plays a critical role in the initial phase of the development of riparian forests. Although some poplar species have fairly large geographic ranges, they are often restricted and exhibit their best development in riparian areas (Wyckoff and Zasada 2005). It has been estimated that up to $99 \%$ of the individuals of this species have disappeared (Lefèvre et al. 1998; Hughes and Rood 2003), mostly as a result of human activities such as the control of river dynamics, wood cutting, and cattle grazing. In recent years, there has been increasing interest in restoring the riparian habitats of European rivers (Arens 
et al. 1998; Hughes et al. 2005). The genetic diversity of $P$. nigra, however, is threatened by the reduction of perturbed areas due to the management of river flows, the latter of which has impacted the regeneration of trees all over Western Europe. Massive introduction of $P$. $x$ euramericana (or $P$. $x$ canadensis) clones and $P$. nigra varieties that readily intercross with native $P$. nigra trees, has also led to a reduction in the genetic diversity of pure $P$. nigra (Frison et al. 1995) and now poplar is facing extinction (Storme et al. 2004). In Britain and Ireland, P. nigra is one of the most rare tree species (Cottrell 2004).

Wild populations can be a valuable source of new genetic material for plant breeding. The natural diversity of plants growing in their natural habitats means that at least some individuals may carry genes of commercial importance, such as those which confer resistance to diseases and insects or are useful in stressful environments (Acquaah 2007). Therefore, it is crucial to secure as much biodiversity as is possible. Due to its economic value and threatened species status, native populations of $P$. nigra were considered a high priority for international collaborative activities on forest genetic resources in Europe (Lefevré et al. 1998). Many attempts have been made to assess the genetic diversity of P. nigra populations (Arens et al. 1998; Rathmacher et al. 2010; Smulders et al. 2008). A project for the in situ conservation of this species was also started as part of the European Forest Genetic Resource Programme (Lefèvre et al. 2001). However, protection of high biodiversity of species is not possible on clone plantation, because it needs huge land area and cost of maintaining, moreover, clonal plantation can be affected by disease or pest.

Seed storage is the most efficient method of protection for many species because it enables the preservation and conservation of a huge amount of genetic diversity ( $\mathrm{Li}$ nington and Pritchard 2001). Additionally, ex situ seed conservation is 100 times cheaper that the in situ preservation of individual trees (Li and Pritchard 2009). Populus seeds, however, have a very short life-span and are sensitive to the combined stress of low moisture and temperature during storage (Hill et al. 2013, Popova et al. 2013). So far, storage of several Populus species and hybrids $(P$. alba, $P$. alba $\times P$. glandulosa, $P$. deltoides, $P$. tremuluoides) have been studied previously (Pence 1996; Hill et al. 2013; Popova et al. 2013). All reports confirmed that standard temperatures of seed banking at 5 or $-20{ }^{\circ} \mathrm{C}$ are not enough to preserve viability of Populus seeds for long term, as longevity for diverse species at such temperatures is relatively short (3-12 years), (Popova et al. 2013). The only large-scale long-term option for the ex situ conservation of species that have short-lived seeds, which are sensitive to desiccation, is cryopreservation. Storage at temperature below $-160{ }^{\circ} \mathrm{C}$ is expected to prolong seed life for hundreds or even thousands of years due to very high reduction of metabolic activities (Walters et al. 2004). The most critical factor affecting cryopreservation of seeds is water content (WC), (Pritchard 2007). When dried to an optimal range of $\mathrm{WC}$, the desiccation of seeds prior to cryopreservation in $\mathrm{LN}$ confers a significant increase in survival (Engelmann 2000). Several studies have demonstrated that desiccation sensitivity is the critical factor for the cryopreservation of seeds from forest tree species (Chmielarz 2009a, b; Popova et al. 2012).

Seeds depending on their desiccation tolerance and ability to storage were categorized to three groups: orthodox, intermediate, and recalcitrant (Roberts 1973; Ellis et al. 1990). Orthodox seeds are tolerant to very low desiccation (below $0.05 \mathrm{~g} \mathrm{~g}^{-1}$ of WC) and storage at subzero temperatures. Recalcitrant seeds do not tolerate drying to relative high moisture content (Roberts 1973) and intermediate seed characterized by the combined sensitivity to low moisture content and temperature (Ellis et al. 1990; Hill et al. 2013). Also hydration window-the range of WC, which allows seeds to tolerate cryogenic temperatures may vary between categories and be very narrow for intermediate seeds (Dussert and Engelmann 2006; Hor et al. 2005) or very wide for orthodox seeds (Chmielarz 2010a, b). Whole recalcitrant seeds did not tolerate cryoexposure and for successful cryopreservation embryonic axes or plumules need to be excised (Chmielarz et al. 2011; Plitta et al. 2014).

Tolerance to desiccation and LN exposure of over a dozen Populus and Salix species was investigated (Hong et al. 1998; Maroder et al. 2000; Popova et al. 2012, 2013; Pence 1996; Hill et al. 2013). Most of them (30 species) were considered as orthodox (Hong et al. 1998; Maroder et al. 2000), and some of them (P. tremuloides and $P$. deltoides) were characterized as intermediate (Pence 1996; Hill et al. 2013). All these reports showed that seed tolerance to WC manipulation and cryopreservation is very variable among species in Salicaceae family (Popova et al. 2013). Therefore, desiccation and storage behavior should be assessed for each species separately and it is difficult to predict in advance to which category investigated seeds should be classified. In the literature, there is information that $P$. nigra seeds, due to very rapid loss of viability during storage, should be classified as recalcitrant (Gosling 2007). However, neither desiccation tolerance nor tolerance to immersion in $\mathrm{LN}$ has been investigated for black poplar seeds, although Tylkowski (2010) stored P. nigra seeds at LN for one day without any negative impact on germination. Also in the literature, there is lack of data about severe drying to $0.05 \mathrm{~g} \mathrm{~g}^{-1} \mathrm{WC}$ or lower of seeds of any Populus sp.

The present study was carried out to quantify the desiccation tolerance of $P$. nigra seeds and their response to 
cryostorage for $24 \mathrm{~h}$. We applied to determine the safe range (SR) of water content at which black poplar seeds could be safely cryostored. Determining the optimal WC for the cryopreservation of $P$. nigra seeds will enable their long-term storage in gene banks tasked with preserving the genetic diversity of forest tree species.

\section{Materials and methods}

Plant material

Seeds were collected from three different 50- to 70-year old trees in May 2010 (Seed lot No. 1) and 2011 (Seed lot No. 2) in Czeszewo (middle-west Poland) near the Warta River $\left(52^{\circ} 8^{\prime} \mathrm{N}\right.$ and $\left.17^{\circ} 30^{\prime} \mathrm{E}\right)$ and from one tree in May of 2002 (Seed lot No. 3) in Torun (centre of Poland) near the Wisła River $\left(53^{\circ} 02^{\prime} \mathrm{N}\right.$ and $\left.18^{\circ} 43^{\prime} \mathrm{E}\right)$. Trees in Czeszewo and Torun were growing in populations of 80-100 individuals. The distance between two trees collected in Czeszewo was approximately $60 \mathrm{~m}$, and the distance between Czeszewo and Torun is approximately $150 \mathrm{~km}$. Due to the fact that seeds from Seed lot 1 and Seed lot 2 originated from the same population therefore at least some seeds could be half-siblings due to pollination from similar parental tree. There were no other poplar plantations or poplar species nearby, ensuring that the seeds used in the study were true seeds of $P$. nigra. Catkins were collected directly from the trees when they ripened and started to open. Catkins were placed in an environmental chamber which was maintained at a constant $15^{\circ} \mathrm{C}$ for $72 \mathrm{~h}$ to allow the catkins to fully open. Seeds were manually separated from their cotton-like seed hairs using a sieve with $2.5 \mathrm{~mm}$ holes and then stored in hermetically sealed polyethylene bags at $3{ }^{\circ} \mathrm{C}$ for 7 days until the commencement of the experiments.

\section{Adjusting the WC of seeds}

Fresh seeds, after extraction from the catkins, had a WC of $0.11 \mathrm{~g} \mathrm{H}_{2} \mathrm{O} / \mathrm{g}^{-1}$ dry mass $\left(\mathrm{g} \mathrm{g}^{-1}\right)$ and were stored at $3{ }^{\circ} \mathrm{C}$ prior to further analysis. Seeds were dried or moistened to various $\mathrm{WC}$ levels prior to immersion in $\mathrm{LN}$ as previously described (Michalak et al. 2013). Seed were moisturized several times with water to obtain $\geq 0.11 \mathrm{~g} \mathrm{~g}^{-1} \mathrm{WC}$, and then left in tightly closed vials for 3 days (Seed lot No. 1 and 2) or 7 days (Seed lot No. 3) of conditioning at $3{ }^{\circ} \mathrm{C}$. Seeds at WC of $\leq 0.11 \mathrm{~g} \mathrm{~g}^{-1}$ were obtained by desiccation over activated silica gel for about 4-6 h $\left(0.07-0.08 \mathrm{~g} \mathrm{~g}^{-1}\right.$ WC), $24 \mathrm{~h}\left(0.04-0.05 \mathrm{~g} \mathrm{~g}^{-1}\right.$ WC) or $48 \mathrm{~h}\left(0.02 \mathrm{~g} \mathrm{~g}^{-1}\right.$ WC). Seed lot No. 1 was adjusted to a range of $0.04-0.37 \mathrm{~g} \mathrm{~g}^{-1}$ WC, Seed lot No. 2 to a of range $0.02-0.35 \mathrm{~g} \mathrm{~g}^{-1} \mathrm{WC}$, and Seed lot No. 3 to a range of $0.04-0.35 \mathrm{~g} \mathrm{~g}^{-1}$ WC. Seed WC (3 replications of 50 seeds each) was determined by drying seeds at $103 \pm 2{ }^{\circ} \mathrm{C}$ for $17 \mathrm{~h}$ each time WC was analyzed.

Assessment of a safe range of seed WC

The range of seed WC that is conducive to safe and successful storage in LN was determined by moistening or desiccating seeds to eight (Seed lot No. 1) or eleven (Seed lot No. 2 and No. 3) different levels of WC in the ranges stated previously. Seeds were placed in vials (Nunc $1.8 \mathrm{ml}$ ) and plunged directly into LN and stored for $24 \mathrm{~h}$. After storage in $\mathrm{LN}$, vials containing seeds were thawed at $40{ }^{\circ} \mathrm{C}$ in a water bath for $5 \mathrm{~min}$. Seeds desiccated to analogous levels of WC were stored for $24 \mathrm{~h}$ at $3{ }^{\circ} \mathrm{C}$ as controls. As a safe range, we assume seed WC range were germinability of seeds were not affected by pre-treatment before cryostorage (desiccation or conditioning) or by immersion in $\mathrm{LN}$ after pre-treatment.

\section{Germination}

Germination tests were conducted using 50 seeds placed on moist filter paper $(70 \mathrm{~mm}$ in diameter) in a Jacobsen apparatus and covered with a plastic lid. This served as one replicate and there were four replicates for each level of desiccation and form of storage. Temperature was maintained at $23{ }^{\circ} \mathrm{C}$ for $22 \mathrm{~h}$ and $27^{\circ} \mathrm{C}$ for $2 \mathrm{~h}$ each day, and light was provided on a $12 \mathrm{~h}$ cycle (irradiance of $22 \mu \mathrm{mol} \mathrm{m} \mathrm{m}^{-2} \mathrm{~s}^{-1}$ ) with illumination being provided during the period with the highest daily temperature. All seeds with an emerging radical, collet hairs, and fully expanded cotyledons after 14 days were considered as germinated.

\section{Statistical analysis}

STATISTICA software was used (StatSoft Polska 1995-2005) for analysis of the data. Analysis of variance (ANOVA) was used to analyze for treatment effects and NIR tests were performed after arc-sin transformation of the data at a significance level of $P=0.05$. Separate one-way ANOVAs were used for analyzing the effect of different WC and cryopreservation on seeds. Additionally, Tukey's tests were performed after arc-sin transformation of the data at a significance level of $P=0.05$ and a two-way ANOVA analyses for the effect of cryopreservation on seeds with different WC was conducted (Supplementary data).

\section{Results}

Desiccation sensitivity of seeds

Fresh, untreated, control seeds from Seed lot No. 1 with a WC of $0.11 \mathrm{~g} \mathrm{~g}^{-1}$ exhibited $47 \%$ germination. Desiccation 

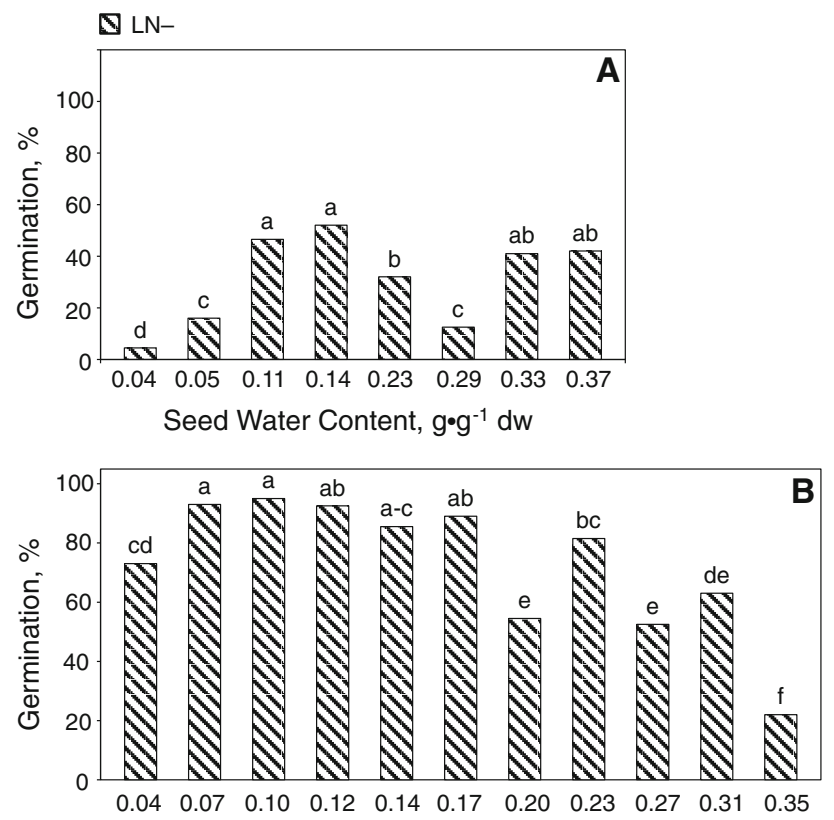

Seed Water Content, $g \bullet \mathrm{g}^{-1} \mathrm{dw}$

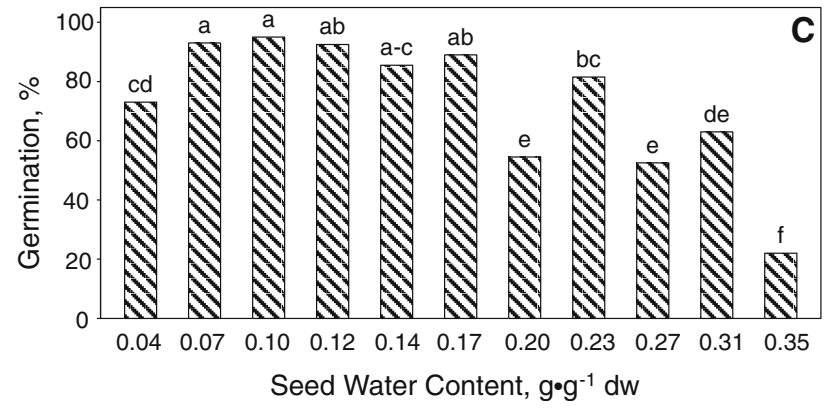

Fig. 1 Percentage of germination of $P$. nigra seeds collected from Seed lot No. 1 (a), Seed lot No. 2 (b), Seed lot No. 3 (c). Seeds desiccated and hydrated to WC levels ranging from 0.04 to $0.37 \mathrm{~g} \mathrm{~g}^{-1}$ (a), 0.02-0.35 g g ${ }^{-1}$ (b), and 0.04-0.35 g g g $^{-1}$ (c). Separate statistical analysis was made for each Seed lot. Values labeled with the same lower-case letter are not significantly different at $P<0.05$, NIR test

of seeds from WC $0.11-0.05 \mathrm{~g} \mathrm{~g}^{-1}$ reduced their germination to $16 \%$, while severe desiccation to $0.04 \mathrm{~g} \mathrm{~g}^{-1} \mathrm{WC}$ resulted in a decline of germination to $5 \%$, (Fig. 1a). Fresh, control seeds from Seed lot No. 2 with a WC of $0.11 \mathrm{~g} \mathrm{~g}^{-1}$ exhibited a very high level of germination $94 \%$ (Fig. 1b). Drying of these seeds to a WC of 0.08 or $0.07 \mathrm{~g} \mathrm{~g}^{-1}$ did not significantly reduce their levels of germination (94 and $92 \%$ of germination, respectively). Further drying of these seeds to a WC of $0.04 \mathrm{~g} \mathrm{~g}^{-1}$ decreased germination to $82 \%$, while seeds desiccated to the lowest level of WC $0.02 \mathrm{~g} \mathrm{~g}^{-1}$ germinated at $67 \%$ (Fig. 1b). Seeds that were collected in Torun and desiccated to a WC of $0.07 \mathrm{~g} \mathrm{~g}^{-1}$ exhibited the same level of germination $(89 \%)$ as control seeds $\left(0.10 \mathrm{~g} \mathrm{~g}^{-1}\right)$ but desiccation to a WC of $0.4 \mathrm{~g} \mathrm{~g}^{-1}$ significantly reduced seeds germination to $78 \%$ (Fig. 1c).
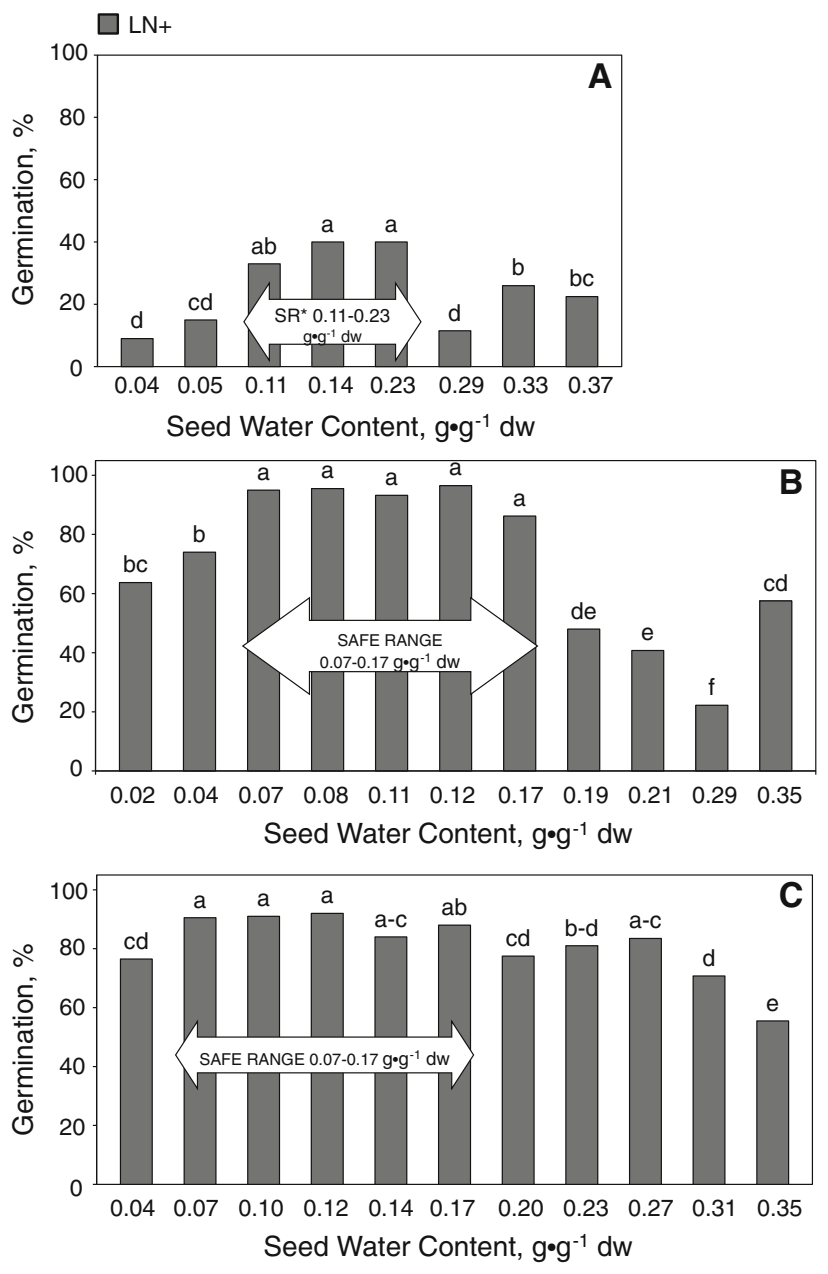

Fig. 2 Percentage of germination of P. nigra seeds collected from Seed lot No. 1 (a), Seed lot No. 2 (b), Seed lot No. 3 (c). Seeds desiccated and hydrated to WC levels ranging from 0.04 to $0.37{\mathrm{~g} \bullet \mathrm{g}^{-1}}^{(\mathbf{a}),}, 0.02-0.35 \mathrm{~g} \mathrm{~g}^{-1}$ (b), and $0.04-0.35 \mathrm{~g} \mathrm{~g}^{-1}$ (c) and subjected to cryopreservation for $24 \mathrm{~h}$. Separate statistical analysis was made for each Seed lot. Values labeled with the same lower-case letter are not significantly different at $P<0.05$, NIR test. SR $*$-safe range

Optimal WC for seed cryopreservation

The range of WC at which germination of cryopreserved seeds was the highest in Seed lot No. 1 was 0.11-0.23 $\mathrm{g} \mathrm{g}^{-1}$ (Fig. 2a). In this safe range, the germination of cryostored seeds was $33-40 \%$, it was similar to the level of germination of seeds that were not subjected to cryostorage (32-52\%). Cryopreserved seeds desiccated to 0.05 or $0.04 \mathrm{~g} \mathrm{~g}^{-1} \mathrm{WC}$ had germination percentage of 15 and $9 \%$, which were significantly lower than germination of control seeds (not cryopreserved) (Fig. 2 A). Cryopreserved seeds with a higher level of WC $(0.29,0.33$ and $\left.0.37 \mathrm{~g} \mathrm{~g}^{-1}\right)$ than fresh seeds exhibited lower germinability (12, 26 and $23 \%$, respectively) than fresh seeds after cryopreservation (Fig. 2a). The hydration of seeds to high 
WCs 0.33 and $0.37 \mathrm{~g} \mathrm{~g}^{-1}$ and their conditioning for 3 days had no effect on seed germination, however, at WC $0.29 \mathrm{~g} \mathrm{~g}^{-1}$ seed germination was reduced to $13 \%$ (Fig. 2a).

Cryopreservation of seeds from Seed lot No. 2 tolerated freezing in LN without any loss in viability when WC was in the range of $0.07-0.17 \mathrm{~g} \mathrm{~g}^{-1}$. In this safe range of WC, germination of cryopreserved seeds was $86-97 \%$. This was similar to the level of germination of non-frozen seeds which was $82-98 \%$ (Fig. 2b). Cryopreservation of seeds desiccated to a WC of 0.04 or $0.02 \mathrm{~g} \mathrm{~g}^{-1}$ exhibited a germination rate of 74 and $64 \%$, respectively. This level of germination was significantly lower than either cryopreserved or non-frozen control seeds with a WC of $0.11 \mathrm{~g} \mathrm{~g}^{-1}$. Cryopreservation of seeds with a WC in the range of $0.19-0.35 \mathrm{~g} \mathrm{~g}^{-1}$ caused a significant reduction in germination from 90 to $38-57 \%$. Seeds at a high WC $\left(0.19-0.35 \mathrm{~g} \mathrm{~g}^{-1}\right)$ had a low percentage $(22-58 \%)$ of germination, regardless whether or not they were frozen in LN (Fig. 2b).

Seeds from the Torun Seed lot No. 3 with a wide of WC $\left(0.07-0.17 \mathrm{~g} \mathrm{~g}^{-1}\right)$ readily survived cryopreservation (Fig. 2c). Highly hydrated seeds $\left(0.31\right.$ and $\left.0.35 \mathrm{~g} \mathrm{~g}^{-1}\right)$ exhibited a significantly lower rate (71 and $56 \%$, respectively) of germination than control seeds which were approximately $90 \%$. Seeds moistened to 0.20 and $0.27 \mathrm{~g} \mathrm{~g}^{-1} \mathrm{WC}$, that were not cryopreserved but only conditioned, had a germination percent of only 55 or $53 \%$, which was significantly lower than the $90 \%$ of germination observed with control seeds having a water content of 0.10$0.12 \mathrm{~g} \mathrm{~g}^{-1}$. Severe desiccation of the seeds from Torun to $0.04 \mathrm{~g} \mathrm{~g}^{-1}$ WC caused a significant loss in the germinability (Fig. 1c). Based on these results, the safe range of WC for seeds from Toruń was considered as $0.07-0.17 \mathrm{~g} \mathrm{~g}^{-1}$. Germination of cryopreserved and non-cryopreserved seeds in this safe range was $89-95 \%$ (Fig. 2c).

\section{Discussion}

\section{Desiccation tolerance}

Seeds of P. nigra from Seed lot No. 2, and Seed lot No. 3 had the highest initial levels of germination (>90\%). These seeds tolerated desiccation to $0.07 \mathrm{~g} \mathrm{~g}^{-1} \mathrm{WC}$, but significantly lost viability after desiccation to a WC of $0.04 \mathrm{~g} \mathrm{~g}^{-1}$ or lower. Seeds from Seed lot No. 1 (Fig. 1a), with a WC of $0.11 \mathrm{~g} \mathrm{~g}^{-1}$, had a much lower initial level of germination $(47 \%)$. This level was reduced even further when seeds were desiccated to a WC of $0.05 \mathrm{~g} \mathrm{~g}^{-1}$. Pence (1996) showed that Populus deltoides seeds survived drying to a WC of $0.08-0.11 \mathrm{~g} \mathrm{~g}^{-1}$. Similar to our results, short-lived seeds of Salix caprea desiccated from 0.08 to
$0.05 \mathrm{~g} \mathrm{~g}^{-1}$ WC significantly decreased germination from 100 to $19 \%$ (Popova et al. 2012). In S. caprea, desiccation tolerance of seeds was correlated with the initial viability of seeds (Popova et al. 2012). In our opinion, seeds of $P$. nigra should be classified as intermediate seeds rather than recalcitrant based on their response to desiccation. This classification contradicts a suggestion that was previously provided by Gosling (2007) that $P$. nigra seeds are recalcitrant, short-lived seeds that can only be stored for four weeks in nondrying conditions at $4{ }^{\circ} \mathrm{C}$ without losing viability (Gosling 2007). Recalcitrant seeds are killed by drying them to a WC as high as $0.25-0.43 \mathrm{~g} \mathrm{~g}^{-1}$ (Pritchard 2004), while intermediate seeds tolerate desiccation to a WC of approximately $0.11-0.13 \mathrm{~g} \mathrm{~g}^{-1}$ (Hong et al. 1998). Additionally, Populus nigra seeds should not be classified as orthodox because they did not tolerate desiccation to a WC $\leq 0.05 \mathrm{~g} \mathrm{~g}^{-1}$ without loss of viability (Roberts 1973). Intermediate seeds lose their viability in cold storage even when they are desiccated (Ellis et al. 1990). Therefore, seeds of $P$. nigra were subjected to cryostorage in order to prove that they fully fit the classification as intermediate seeds. Our data are in concordance with previous results (Pence 1996; Hill et al. 2013) showing that short-lived seeds of $P$. deltoides or $P$. tremuloides should be categorized as intermediate. On the other hand, they are in contradiction with results obtained by Maroder et al. (2000) and Hong et al. (1998) who classified Salix seeds as orthodox. Contrary to our results also P. alba $x$ glandulosa seemed to have orthodox type of behavior (Popova et al. 2013). Our data support the claim that in Salicaceae family desiccation tolerance varies significantly between species (Popova et al. 2013). Therefore, for each species of Salicaceae desiccation, tolerance should be investigated separately.

Increasing the WC of seeds

Increasing the WC of seeds above the level of freshly collected seeds had different effects on germination depending on initial seed viability. Seeds from Seed lot No. 3 (Fig. 2c) and Seed lot No. 2 (Fig. 2b) exhibited a high initial viability ( $>90 \%)$. Hydration of these seeds to a WC $0.12-0.17 \mathrm{~g} \mathrm{~g}^{-1}$ did not have any effect on seed germination. However, further hydration to a WC over $0.17 \mathrm{~g} \mathrm{~g}^{-1}$, resulted in a significant reduction in germination. Similarly negative effect of highly vigorous seed moisturizing was observed during the development of seedlings of S. caprea clones (Popova et al. 2012). Observed decrease in viability of $P$. nigra seeds after their moisturizing may be connected with aging process which runs faster in seeds at higher WC. Results show that if WC of $P$. nigra seeds is higher than $0.17 \mathrm{~g} \mathrm{~g}^{-1}$ they deteriorate very fast even during storage at $3{ }^{\circ} \mathrm{C}$. 
Table 1 Safe ranges of seed water content (WC) and moisture content (MC) of forest tree species required for successful cryopreservation

\begin{tabular}{lllll}
\hline Type of seeds & Species & Safe range WC $\left(\mathrm{g} \mathrm{g}^{-1}\right)$ & Safe range MC $(\%)$ & Literature \\
\hline Orthodox & Black alder (Alnus glutinosa) (L.) Gaertn. & $0.026-0.23$ & $2.7-19.2$ & Chmielarz 2010a \\
& European ash (Fraxinus excelsior) L. & $0.075-0.24$ & $7.2-19.5$ & Chmielarz 2009a \\
& Silver birch (Betula pendula) Roth & $0.02-0.31$ & $2.0-23.2$ & Chmielarz 2010b \\
& European hazelnut (Corylus avellana) L. & $0.08-0.10$ & $7.2-9.1$ & Michalak et al. 2013 \\
Intermediate & Black polar (Populus nigra) L. & $0.11-0.17$ & $10-15$ & present study \\
& Easter cottonwood (Populus deltoides) Bartr. & $0.085-0.17$ & $8-15$ & Pence 1996 \\
& Mazzard cherr (Prunus avium) L & $0.1-0.2^{*}$ & $9.0-16.9 *$ & Chmielarz 2009b \\
\hline
\end{tabular}

* After germination, seedling emergence from seeds stored in LN was lower than from non-frozen seed. Seed moisture content (MC) expressed in $\%$ ( $F W$ fresh weight basis)

In contrast, the germination of seeds from Seed lot No. 1, which had a lower initial viability compared with Seed lot No. 2, was not affected by increasing their level of hydration, with the exception of a WC of $0.29 \mathrm{~g} \mathrm{~g}^{-1}$. These results were contrasted those obtained by Popova et al. (2012) and Maroder et al. (2000) who reported that lower germination of $S$. caprea, $S$. alba and $S$. matsudana seeds could be improved by moderate rehydration before sowing. The difference in response to rehydration of $S$. caprea, $S$. $a l b a$ and $S$. matsudana and $P$. nigra seeds could result from different methodology of rehydration ( $24 \mathrm{~h}$ in case of Salix species and 3-7 day in case of $P$. nigra seeds) or this trait may be connected with family and different tree species even closely related like Salix and Populus could react at different way to moisturizing of seeds.

\section{Cryopreservation of seeds}

Seeds from all of the investigated provenances tolerated cryopreservation when seeds were desiccated prior to immersion in $\mathrm{LN}$ to a $\mathrm{WC}$ in the ranges defined in our study. Only a slight variation in the safe range of WC was observed for the individual Seed lot. Safe ranges were defined as a WC of $0.11-0.23 \mathrm{~g} \mathrm{~g}^{-1}$ for Seed lot No. 1 (Fig. 2a) and 0.07-0.17 $\mathrm{g} \mathrm{g}^{-1}$ for Seed lot No. 2 (Fig. 2b), and $0.07-0.17 \mathrm{~g} \mathrm{~g}^{-1}$ for the Seed lot No. 3 (Fig. 2c). WCs in the range of $0.07-0.10 \mathrm{~g} \mathrm{~g}^{-1}$ were not investigated for Seed lot No. 1 due to an insufficient number of seeds. Our data indicate that in the range of $0.11-0.17 \mathrm{~g} \mathrm{~g}^{-1} \mathrm{WC}$, seeds tolerated cryopreservation regardless of their initial viability, reaction to water content adjustment, year of collection, or origin. Pence (1996) reported on cryopreservation of seeds of Populus deltoides. Her data indicate that seeds of this species can be successfully cryopreserved when they are desiccated to a WC in the range of $0.085-0.17 \mathrm{~g} \mathrm{~g}^{-1}$ prior to immersion in LN. Our data indicated that the efficiency of cryopreservation is dramatically reduced when seeds are desiccated to a WC lower than $0.07 \mathrm{~g} \mathrm{~g}^{-1}$. Thus, the results presented by us and Pence (1996) are in accordance. The safe range (0.11-0.17 $\left.\mathrm{g} \mathrm{g}^{-1}\right)$ of WC for the successful cryopreservation of seeds obtained in the present study is narrow in comparison to the safe ranges observed for most of orthodox seeds of other tree species (Table 1). Only Corylus avellana seeds which were considered as orthodox (Michalak et al. 2013) have more narrow safe range of WC.

Similar to $P$. nigra seeds narrow safe ranges were observed in investigations concerning cryopreservation of Prunus avium, and Populus deltoides seeds. All species are considered to produce seeds with intermediate type of behavior (Chmielarz 2009b; Pence 1996). This support our findings that even in terms of response to temperature of LN P. nigra react as seeds classified as intermediate.

Previous reports about viability of seeds after storage at subzero temperatures of $P$. nigra seeds showed that these short-lived seeds could not be long-term stored (Gosling 2007). Therefore, seed banking of $P$. nigra seeds has not been considered a feasible option. However, results of this study demonstrated that cryostorage of $P$. nigra seeds is possible, even though the routine use of cryopreservation is still limited. However, growing number of gene banks and botanical gardens use cryopreservation on a large scale for different types of material (Engelmann 2011); for example, the U.S. Department of Agriculture-Agricultural Research Service (USDA-ARS) National Center for Genetic Resources Preservation (NCGRP), Fort Collins, CO, USA (Walters et al. 2004), The National Bureau for Plant Genetic Resources (NBPGR; New Delhi, India), (Mandal 2000) and Center for Conservation and Research of Endangered Wildlife, CryoBioBank, Cincinnati, USA (http://cincinnatizoo.org/conservation/crew/). Cryopreservation is also applied to intermediate seeds, such as coffee seeds which are preserved in the Tropical Agricultural Research and Higher Education Center (CATIE, Cañas, Guanacaste, Costa Rica) and in the IRD (Montpellier, France) (Engelmann 2011). We proofed that cryostroage of $P$. nigra seeds can be used for long-term protection of the genetic biodiversity of this species in gene banks. 


\section{Conclusions}

Summarizing $P$. nigra seeds can be desiccated to a WC of $0.07 \mathrm{~g} \mathrm{~g}^{-1}$ without a loss in viability. When seeds of $P$. nigra are exposed to lower levels of WC $\left(\leq 0.05 \mathrm{~g} \mathrm{~g}^{-1}\right)$, their viability is significantly decreased. Our data indicate that seeds of this species could be successfully cryopreserved to preserve its genetic diversity if seeds are desiccated to a WC in the safe range of $0.11-0.17 \mathrm{~g} \mathrm{~g}^{-1}$ prior to immersion in LN without any reduction in the germinability, regardless of their initial viability, origin and year of collection. Based on their desiccation tolerance, ability to withstand immersion in LN, we classified $P$. nigra seeds as intermediate.

Acknowledgments We thank Elżbieta Drzewiecka-Pieniężna, Elżbieta Nogajewska, Danuta Szymańska and Magdalena Sobczak for providing technical assistance. This work was supported by a grant from the National Science Centre, Poland (No. NN309 429 138). We would like to thank Reviewers for their comments which allow us to improve the manuscript.

Open Access This article is distributed under the terms of the Creative Commons Attribution License which permits any use, distribution, and reproduction in any medium, provided the original author(s) and the source are credited.

\section{References}

Acquaah G (2007) Principles of plant genetics and breeding. Blackwell, Oxford

Arens P, Coops H, Jansen J, Vosman B (1998) Molecular genetic analysis of black poplar (Populus nigra L.) along Dutch rivers. Mol Ecol 7:11-18

Chmielarz P (2009a) Cryopreservation of dormant European ash (Fraxinus excelsior) orthodox seeds. Tree Physiol 29:1279-1285

Chmielarz P (2009b) Cryopreservation of dormant orthodox seeds of forest trees: mazzard cherry (Prunus avium L.). Ann For Sci 66:405

Chmielarz P (2010a) Cryopreservation of conditionally dormant orthodox seeds of Betula pendula. Acta Physiol Plant 32:591-596

Chmielarz P (2010b) Cryopreservation of the non-dormant orthodox seeds of Ulmus glabra. Acta Biol Hung 61:224-233

Chmielarz P, Michalak M, Palucka M, Wasilenczyk U (2011) Successful cryopreservation of Quercus robur plumules. Plant Cell Rep 30:1405-1414

Cottrell J (2004) Conservation of Black Poplar (Populus nigra L.) in Forest commission. http://www.forestry.gov.uk/pdf/FCIN057. pdf/\$FILE/FCIN057.pdf. Accessed 9 Aug 2014

Dussert S, Engelmann F (2006) New determinants of coffee (Coffea arabica L.) seed tolerance to liquid nitrogen exposure. Cryo-Lett 27:169-178

Ellis RH, Hong TD, Roberts EH (1990) An intermediate category of seed storage behaviour?: i. Coffee. J Exp Bot 41:1167-1174

Engelmann F (2000) Cryopreservation of tropical germplasm. In: Engelmann F, Takagi $\mathrm{H}$ (eds) Current research progress and application, Japan International Research Centre for Agricultural Sciences, Tsukuba, pp 8-20

Engelmann F (2011) Use of biotechnologies for the conservation of plant biodiversity. In Vitro Cell Dev Biol Plant 47:5-16
Frison E, Lefevre F, de Vries S, Turok J (1995) Populus nigra network. http://www.euforgen.org/fileadmin/www.euforgen. org/Documents/Meeting_Summaries/PN02_meeting_summary. pdf. Accessed 5 December 2013

Gosling P (2007) Raising trees and shrubs from seeds; practice guide. Forestry Commission 231 Corstorphine Road, Edinburgh, UK

Hill LM, Haiby K, Volk GM, Walters CT (2013) "Intermediate" seed storage physiology: populus as a natural model system. International Society for Horticultural Science Meeting, p. 88

Hong TD, Linington S, Ellis RH (1998) Compendium of information on seed storage behaviour, vol I. Royal Botanic Gardens, Kew

Hor YL, Kim J, Chabrillange U, Sinniah R, Engelmann F, Dussert S (2005) Optimal hydration status for cryopreservation of intermediate oily seeds: citrus as a case study. Ann Bot 95:11531161

Hughes FMR, Rood SB (2003) The allocation of river flows for the restoration of woody riparian and floodplain forest ecosystems: a review of approaches and their applicability in Europe. Environ Manag 32:12-33

Hughes FMR, Colston A, Mountford OJ (2005) Restoring riparian ecosystems: the challenge of accommodating variability and designing restoration trajectories. Ecol Soc 10(1), 12. online URL: http://www.ecologyandsociety.org/vol10/iss1/art12/

Lefèvre F, Légionnet A, de Vries S, Turok J (1998) Strategies or the conservation of a pioneer tree species, Populus nigra L. Eur Genet Sel Evol 30:181-196

Lefèvre F, Barsoum N, Heinze B, Kajba D, Rotach P, de Vries SMG, Turok J (2001) In situ conservation of Populus nigra EUFORGEN 1-64. http://www.bioversityinternational.org/uploads/tx news/In_situ_conservation_of_Populus_nigra_741.pdf

Li DZ, Pritchard HW (2009) The science and economics of ex situ plant conservation. Trends Plant Sci 14:614-621

Linington SH, Pritchard HW (2001) Gene banks. In: Levin SA (ed) Encyclopedia of biodiversity, vol 3. Academic Press, New York, pp $165-181$

Mandal BB (2000) Cryopreservation research in India: current status and future perspectives. In: Engelmann F, Takagi H (eds) Cryopreservation of tropical plant germplasm-current research progress and applications. JIRCAS, Tsukuba, pp 282-286

Maroder HL, Prego IA, Facciuto GR, Maldonado SB (2000) Storage behaviour of Salix alba and Salix matsudana seeds. Ann Bot 86:1017-1021

Michalak M, Plitta BP, Chmielarz P (2013) Desiccation sensitivity and successful cryopreservation of oil seeds of European hazelnut (Corylus avellana). Ann Appl Biol 163:351-358

Pence VC (1996) Germination, desiccation and cryopreservation of seeds of Populus deltoides. Seed Sci Technol 24:151-157

Plitta BP, Michalak M, Naskręt-Barciszewska MZ, Barciszewski J, Chmielarz P (2014) DNA methylation of Quercus robur L. plumules following cryo-pretreatment and cryopreservation. Plant Cell Tiss Org 117:31-37

Popivshchy II, Prokazin AE, Routkovsky LV (1997) Black poplar in the Russian Federation. In: Turok J, Lefevre F, de Vries S, Toth B (eds). Populus nigra network. Report of the third meeting, IPGRI, Rome, pp 46-52

Popova EV, Hyun KD, Hee HS, Pritchard HW, Cheon LJ (2012) Narrowing of the critical hydration window for cryopreservation of Salix caprea seeds following ageing and a reduction vigour. Cryo-Lett 33:219-230

Popova EV, Kim DH, Han SH, Moltchanova E, Pritchard HW, Hong YP (2013) Systematic overestimation of Salicaceae seed survival using radicle emergence in response to drying and storage: implications for ex situ seed banking. Acta Physiol Plant 35:3015-3025

Pritchard HW (2004) Classification of seed storage 'types' for ex situ conservation in relation to temperature and moisture. In: 
Guerrant EO, Havens K, Maunder M (eds) Ex situ plant conservation: supporting species survival in the wild. Island Press, Washington, pp 139-161

Pritchard HW (2007) Cryopreservation of desiccation tolerant seeds. In: Day JG, Stacey GN (eds) Cryopreservation and freeze-drying protocols. Human Press Inc Totowa, New Jersey, pp 183-199

Rathmacher G, Niggemann M, Köhnen M, Ziegenhagen B, Bialozyt R (2010) Short-distance gene flow in Populus nigra L. accounts for small-scale spatial genetic structures: implications for in situ conservation measures. Conserv Genet 11:1327-1338

Roberts EH (1973) Predicting the storage life of seed. Seed Sci Technol 1:499-514

Smulders MJM, Cottrell JE, Lefévre F, van der Schoot J, Arens P, Vosman B, Tabbener HE, Grassi F, Fossati T, Castiglione S, Krystufek V, Fluch S, Burg K, Vornam B, Pohl A, Gebhardt K, Alba N, Agũndez D, Maestro C, Notivol E, Volosyanchuk R, Pospíśková M, Bordács $\mathrm{S}$, Bovenschen J, van Dam BC, Koelewijn HP, Halfmaerten D, Ivens B, van Slycken J, Vanden Broeck A, Storme V, Boerjan W (2008) Structure of the genetic diversity in black poplar (Populus nigra L.) populations across European river systems: consequences for conservation and restoration. For Ecol Manag 255:1388-1399

Storme V, Vanden Broeck A, Ivens B, Halfmaerten D, Van Slycken J, Castiglione S, Grassi F, Fossati T, Cottrell JE, Tabbener HE,
Lefévre F, Saintagne C, Fluch S, Krystufek V, Burg K, Bordács S, Borovics A, Gebhardt K, Vornam B, Pohl A, Alba N, Agfflndez D, Maestro C, Notivol E, Bovenschen J, van Dam BC, van der Schoot J, Vosman B, Boerjan W, Smulders MJM (2004) Ex-situ conservation of black poplar in Europe: genetic diversity in nine gene bank collections and their value for nature development. Theor Appl Genet 108:969-981

Tunçtaner K (1995) Conservation of genetic resources of Populus nigra in Turkey. In: Frison E, Lefevre F, de Vries S, Turok J (eds), Populus nigra network. Report of the first meeting, IPGRI, Rome, pp 41-44

Tylkowski T (2010) Przekształcenia w składzie dendroflory w dolinie środkowej Warty [Transformation of dendroflora composition in the middle valley of the Warta River]. Acta Sci Pol. Administratio Locorum 9:117-124

Vanden Broeck A (2003). Technical guidelines for genetic conservation and use for European black poplar (Populus nigra). International Plant Genetic resources Institute, EUFORGEN, Rome, Italy

Walters C, Wheeler L, Stanwood P (2004) Longevity of cryogenically stored seeds. Cryobiology 48:229-244

Wyckoff G, Zasada JC (2005) Populus L., poplar. In: Bonner F (ed) Woody plant seed manual. Agric. Handbk. 727. Washington: USDA Forest Service pp 856-871 